Saša Redžić

UDK: 904:739.1"652"(497.11)

Archaeological Institute Belgrade

ID BROJ: 196126476

sasa.redzic@gmail.com

Original research article

Ilija Danković

Archaeological Institute Belgrade

Received: July 08, 2011

Accepted: September 05, 2011

\title{
A UNIQUE FIND OF A BELT SET FROM VIMINACIUM
}

\begin{abstract}
During the archaeological research of the Viminacium necropolis "Pecine", a twofold massive belt set was discovered, made of a silver-plated copper alloy. When closed, the belt set partly resembles Hercules' knot. Since we are dealing with a unique find with no known parallels, the question arises if it is generally just to describe this object as belt set.
\end{abstract}

\section{KEY WORDS: VIMINACIUM, BELT SET, UNIQUE FIND.}

During the archaeological research of the Viminacium necropolis "Pećine", nearly 6.800 graves, and more than 13.500 different artefacts, some of which represent unique specimens regarding even the whole territory of the Roman empire. One of them is a two folded massive belt-buckle, made of a copper alloy, later silver-plated. ${ }^{1}$ Both parts of the belt-buckle are almost identical: the only difference is that one of them possesses an ornament inlayed on its loop. The length of each piece measures $10,3 \mathrm{~cm}$ and their width is 10,2 $\mathrm{cm}$. On ends of both of the parts there are dam-

1 The belt-set was noted in the field documentation under number C- 10000 , discovered in the skeletal grave G-3388. aged hinges of unknown purpose. The hinges lean upon grids which run from the middle towards the endings, resembling propellers. The grids' endings, with button-shaped bumps in the middle, end semi-sperically. Each side of these semispherically endings is decorated with one short vault. On the back-sides of the grids three flathammered nails are located each of them 2-4 mm high, clearly indicating that they were used for fixing onto the leather. The other side of the grids was used for leaning of the loops used for fastening the belt-buckle. Already mentioned ornament consists of two pelta-shaped parts turned upsidedown, with a rhomboidal plate between them. On both sides of the pelts there is an "S"-shaped orna-

\footnotetext{
* The article results from the project: IRS - Viminacium, Roman city and legionary camp - research of material and non material culture of inhabitants by using modern technologies of remote sensing, geophysics, GIS, digitalisation and 3D visualisation (no 47018), funded by Ministry of Education, Science and Technological Development of the Republic of Serbia.
} 

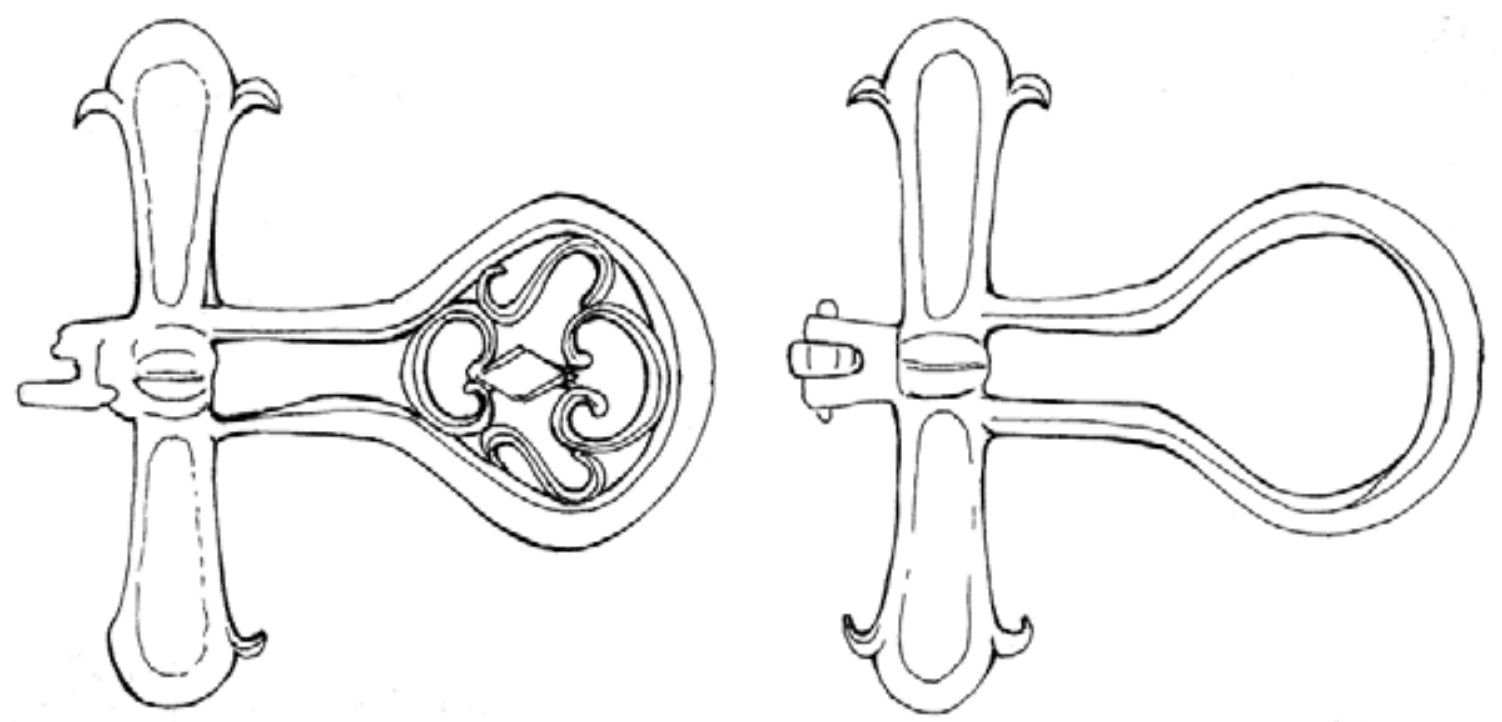

Figure 1. Single parts of the here presented twofolded belt-buckle

ment. If we accept the hypothesis that the buttons were used for fastening onto the leather, hinges should then be considered as carriers of a metal ornament fastened on the front side of the strap.

When closed, as shown on figure 2, the belt-buckle resembles Hercules' knot. This is just a conditional comparison, since only one loop goes around the endings of the other, which is understandable, because if the loops were intertwined, permanent connection would be formed, and belt set couldn't be untied without damaging it. If the resemblance with Hercules' knot would be trustworthy, maybe its owner could be brought in connection with his cult.

Since we were not able to find any analogies for the forementioned artefact in the literature that stood at our disposal, we cannot tell for sure that we are dealing with a belt-buckle at all. Here, the opinion of our colleague D. Spasić-Đurić should be mentioned, because she described this find as a belt-buckle. ${ }^{2}$ The fact supporting the opinion that this actualy is a belt-buckle is that it was a grave-good, placed between the legs of a deceised male. A coin of Phillip I, also found in this grave, dates it in the middle of the $3^{\text {rd }}$ century.

\section{REZIME UNIKATNI NALAZ POJASNE GARNITURE IZ VIMINACIJUMA}

\section{KLJUČNE REČI: VIMINACIUM, POJASNA GARNITURA.}

Među više od 13500 nalaza sa viminacijumske nekropole „Pećine“ jedan predmet se svojom originalnošću i luksuznom izradom naročito ističe. Radi se o dvodelnoj masivnoj pojasnoj garnituri izrađenoj od posrebrene legure bakra. $\mathrm{Na}$ osnovu izgleda kopče kada je sklopljena možemo primetiti njenu delimičnu sličnost sa Herkulovim čvorom. Kako se radi o jedinstvenom nalazu za koji nismo uspeli da pronađemo analogije, postoji sumnja u vezi svrstavanja ovog predmeta u pojasne garniture. Na zaključak da se ipak radi pojasnoj garnituri navodi nas činjenica da je nađena u grobu između nogu inhumiranog pokojnika muškog pola. Grobni prilog koji vremenski determiniše ovaj nalaz u sredinu III veka predstavlja novčić Filipa I.

2 Spasić-Đurić 2002, 74, Slika 53. 


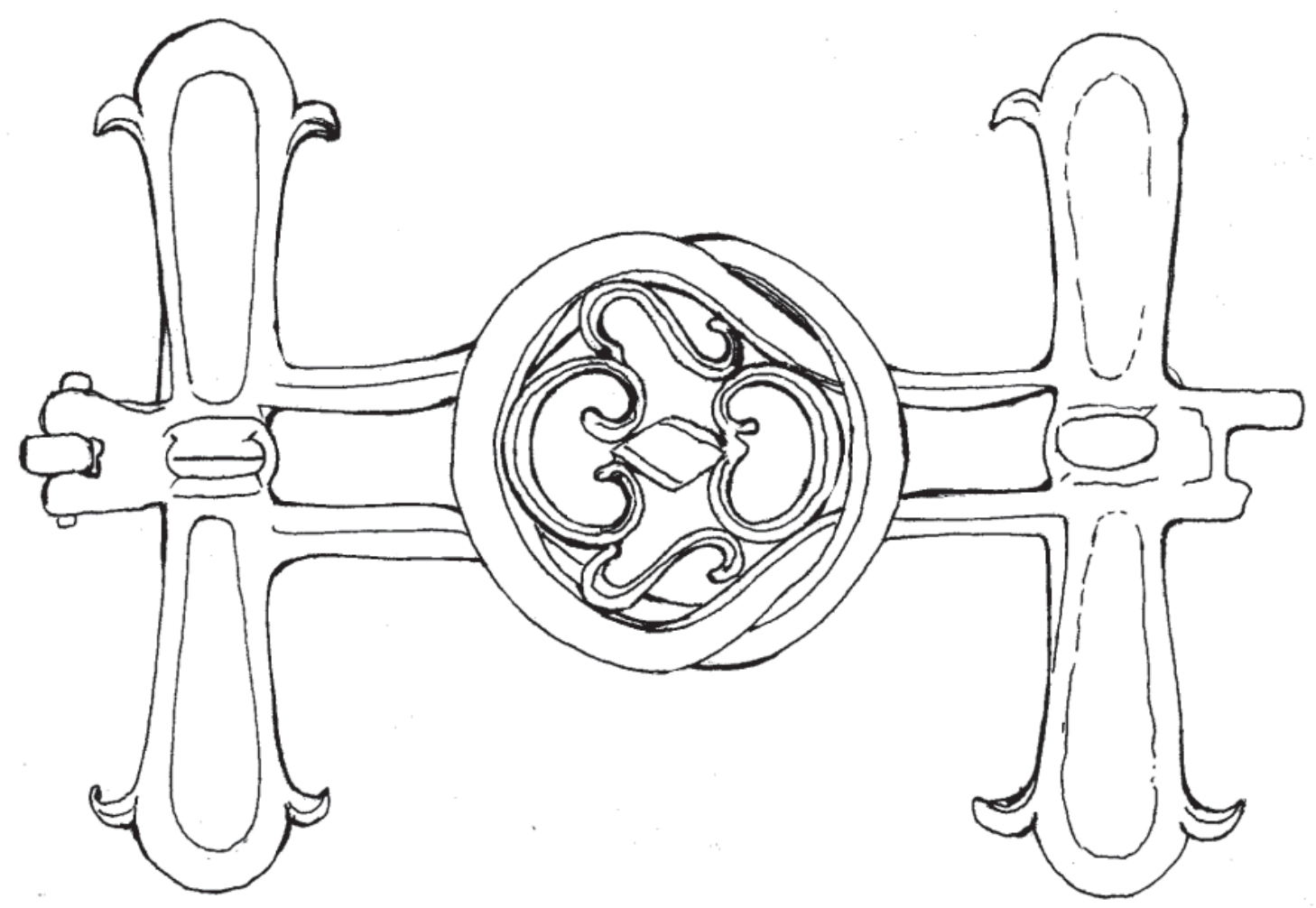

Figure 2. The way of closing the presented twofolded belt-buckle

\section{BIBLIOGRAPHY}

\section{Fischer 1988}

T. Fischer, Zur römischen Officierausrüstung im 3. Jahrhundert n. Ch., Bayerische Vorgeschichtsblätter 53, 167-190.

\section{Oldenstein 1976}

J. Oldenstein, Zur Ausrüstung römischer Auxiliareinheiten, Bericht der Römisch-Germanischen Kommission des Deutschen Archäologischen Instituts 57 (1976), Frankfurt 1977.

\section{Spasić-Đurić 2002}

D. Spasić-Đurić, Viminacijum glavni grad rimske provincije Gornje Mezije, Požarevac 2002. 